\section{Using vocabulary profile for pair taping to improve speaking practices at a class for English as a foreign language}

Ichiyama, Yoko

Kyoritsu Women's University, Japan (yichiyama@kyoritsu-wu.ac.jp)

Received: 6 April 2019

Available Online: 20 August 2019
Revised: 8 July 2019 DOI: $10.5861 /$ ijrse. 2019.4008

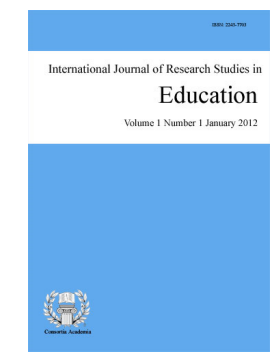

ISSN: $2243-7703$ Online ISSN: 2243-7711

OPEN ACCESS

\title{
Abstract
}

The improvement of speaking proficiency is deemed essential in classrooms of English as a foreign language in Japan, but the amount of exposure to improve fluency is limited. Pair taping is a fluency-focused activity where learners record their conversations inside or outside classrooms, which is considered beneficial because it provides opportunities to speak more in a target language. Numerous studies on pair taping indicate that it has a positive impact on motivation to speak in a target language, but less is known about lexical gains as a result of pair taping. The aims of the study are to examine whether the vocabulary profile improves after learners participate in pair taping for one month and the impact of pair taping on leaner's motivation in regard to lexical gain. There were no significant differences in the vocabulary profiles between before and after the exposure to pair taping except for the amount of words $(t(49)=-3.98 ; p=.0001)$. Many learners, however, reported improved motivation to speak English, as well as increased interest in improving their vocabulary profiles while speaking English. These results indicate a need to provide more opportunities to practice speaking, as well as to raise learners' awareness towards vocabulary sophistication with the help of pair taping.

Keywords: pair taping; English as a Foreign Language (EFL); speaking fluency; vocabulary profile; motivation 


\section{Using vocabulary profile for pair taping to improve speaking practices at a class for English as a foreign language}

\section{Introduction}

Researchers and practitioners involved in the teaching of English as a foreign language (EFL) have continually expressed particular concerns about improving oral communication skills over the last several decades (Gudu, 2015; Albino, 2017). The trend is illustrated in the series of revisions and reforms proposed by the Ministry of Education, Culture, Sports, Science, and Technology (MEXT) in Japan. For example, the MEXT announced a 5-year action plan to cultivate "Japanese with English Abilities" (MEXT, 2003). In this plan, several proposals for revisions of English education were advanced, such as an allocation of assistant language teachers in secondary education to increase the opportunities to use English in language classrooms, as well as an introduction of English subjects in primary education, where the development of positive attitude towards oral communication in English was considered to be crucial in classrooms (Kimura, Nakata, Ikeno, Naganuma, \& Andrews, 2017).

The major focus of these reforms was to foster oral communication skills in English, but many Japanese learners of English still express a lack of confidence in speaking English (Ohata, 2005; Yanagi \& Baker, 2016; Humphries, Burns, \& Tanaka, 2015). For example, Ohata (2005) interviewed five Japanese learners of English and identified that many learners felt anxious when they had to speak English in classrooms. Yanagi and Baker (2016) administered a questionnaire and interviewed 38 Japanese learners of English in Australia regarding the challenges of oral communication in classrooms. Yanagi and Baker concluded that the lack of opportunities to practice English oral communication skills in Japan resulted in the learners often experiencing difficulty in conveying their opinions and thoughts in the classrooms. The lack of opportunities to practice English speaking in classrooms in Japan has been acknowledged in several studies (Kubo, 2009; King, 2012). Kubo (2009) reported that learners attributed their lack of confidence in speaking English to the limited opportunities to practice speaking English. King (2012) also reported that a surprisingly large amount of English class hours were dominated by silence, and each learner only contributed to one percent of overall classroom hours by self-initiating a talk in English classrooms at Japanese universities.

Of the numerous approaches regarding the development of oral communication skills in English, studies on pair taping indicate that pair taping has a positive impact on motivation to speak in the target language, but less is known about lexical gains as a result of pair taping. Thus, the aim of this research is to examine whether vocabulary profiles improve after learners participate in pair taping for one month. The study also explores whether there is a positive impact on leaner's motivation towards lexical gains.

\section{Literature Review}

\subsection{Development of oral communication skills}

Although many approaches have been proposed by which learners can develop oral communication skills, an ability that requires learners to concentrate on developing various cognitive skills, it is still assumed to be one of the most challenging skills to acquire especially in EFL classrooms (Burns \& Hill, 2013; Derakhshan, Khalili, \& Beheshti, 2016; Raba, 2017; Nunan, 1999). The central skills needed for effective oral communication are conceptualization (an ability to select the appropriate content of the spoken interaction), formulation (a linguistic knowledge to express one's ideas accurately) and articulation (an ability to express your ideas with appropriate pronunciation, accent and stress). Nunan (1999) stresses the need to maximize learners' opportunities to speak in the target language in the classroom. Derakhashan, Khalili, and Beheshti (2016) remind us that there is a need to 
explore materials, activities, and instruments that can contribute to the development of an appropriate learning environment in the EFL classroom. Raba (2017) adds that implementing appropriate learning techniques is important for improving communication skills and enhancing students' motivation to speak in English. Nakatani (2006) argues that the development of communication strategies, especially achievement or compensatory strategies, are important for acquiring communicative proficiency in a target language. The achievement or compensatory strategies enable the learners to express their ideas and thoughts by utilizing every resource available. The strategies are the major features of a good speaker while, low-proficiency learners, when faced with difficulties, tend to use reduction or avoidance strategies where they simply avoid or give up conveying their messages or opinions.

Brown (2001) has proposed six types of speaking activities in language classrooms to improve speaking communication skills: imitative, intensive, responsive, transactional, interpersonal, and extensive. Imitative activities focus on practicing and repeating a term or phrase in order to achieve accurate pronunciation. Intensive activities focus on the grammatical features of the language, while responsive activities aim to develop learners' ability to reply to an inquiry or salutation. Transactional activities ask learners to formulate longer sentences and extended dialogues compared to responsive activities, where the focus is on conveying or exchanging specific information between the speakers. Interpersonal activities also focus on practicing longer dialogues while the major focus is on maintaining the conversation, paying attention to the social relationship between the speakers, rather than exchanging information or facts. Extensive activities focus on developing learners' skills to formulate extended monologues such as speeches and oral reports and expressing their opinions and suggestions.

\subsection{Pair taping and its significance}

Pair taping (or partner taping) is a speaking-focused activity with the major aims of practicing fluency and increasing learners' motivation to speak in English (Kluge \& Taylor, 1999, 2000; Schneider, 1993, 1997, 2001). According to Schneider (2001), pair taping "is a fluency practice in which learners record themselves speaking freely in pairs" (p. 1). According to Schneider, exposing learners to speaking English freely on a regular basis (e.g., three to four times a week) provides learners with confidence, and they are therefore more prone to speak English outside the classroom. Sato and Lyster (2012) also point out that providing learners with the chance to converse with their peers enables them to produce more than when they are required to converse with native language speakers. Derakhashan, Khalili, and Beheshti (2016) also state that pair taping is beneficial for developing learners' responsibility for their learning.

Several studies have examined the impact of pair taping in the context of EFL, especially in Japan, and many researchers reported increases in learners' confidence in speaking English (Angga, 2013; Herlina \& Holandiyah, 2015; Kubo, 2007, 2009, 2013; Setiyorini, 2013; Syamdianita, Ismail, \& Nur, 2018). Kubo (2009) reported a rise in learner fluency and confidence after introducing pair taping to 12 first-year English literature majors in a women's junior college in Tokyo. The learners submitted a 23-minute recording and a reflection sheet every week, in which they reported their reflections on their recordings (e.g., strengths and weaknesses). The learners received written comments from the researcher on their performance. The comments mainly consisted of encouragement about their performance rather than critique about their grammatical mistakes or inappropriate use of English during pair taping.

At the end of a semester, Kubo administered a questionnaire regarding the changes in learners' views about speaking English. The learners made progress in all aspects, including motivation and willingness to engage in both speaking English and pair taping. Furthermore, the total number of words that learners spoke in each taping increased in all pairs except one. Schneider (2001) obtained similar results when comparing learners' attitudes towards speaking English between a group of learners who chose pair taping and those who chose classroom learning. The pair-taping learners were required to record a 22-minute unstructured conversation every week. The results indicated that those who participated in pair taping felt more enjoyment and confidence in speaking English than those who participated in classroom learning. 


\subsection{Lexical profile analysis and its significance}

Lexical profile analysis or vocabulary profile analysis focuses on the frequency of words that appear in particular written or spoken texts. A great many studies have been done on written texts in particular (Engber, 1995; Laufer \& Nation, 1995). Engber (1995) reported that writing proficiency correlated well with lexical proficiency after assigning an English essay to 66 learners with various linguistic backgrounds. Laufer and Nation (1995) obtained similar results when examining two English essays from each of 65 postgraduate learners in three different proficiency groups (low, medium, and high) and comparing their lexical profiles. The essays' lexical profiles correlated well with the learners' proficiency levels.

Research indicates that learners' vocabulary knowledge correlate positively with their English proficiency (Iwashita, 2005; Kim, 2010). Iwashita (2005) compared English proficiency with lexical profiles in speaking tasks and reported that test takers with high proficiency demonstrated more knowledge of academic vocabulary than those with low proficiency.

While numerous studies have focused on using lexical profile analysis to assess the learners' language proficiency or measuring the level of materials used in the classroom, little has been said about the influence of learners using lexical profile analysis in order to acknowledge their progress (Daller \& Xue, 2009; Jin, Guo, Mak, $\& \mathrm{Wu}, 2017)$. As Nakatani (2006) points out, when low-proficiency learners face a communication deficit caused by language difficulties, the use of negative coping strategies such as message abandonment increases, while positive strategies such as negotiation for meaning while speaking decreases compared to the habits of high-proficiency learners. By implementing the activity of lexical analysis, learners can objectively measure the amount and the level of language they use during their conversation.

\section{Research Methodology}

Based on the literature review, this research explores the influence of pair taping and lexical profile analysis on EFL learners' progress in lexical use and motivation to speak in English.

\subsection{Research design}

In this research, a mixed-method research framework is used to investigate whether the learners' language profile and motivation to speak has improved as a result of the implementation of pair taping. A case study design was used, in which audio-taped learner interaction and a semi-structured questionnaire served as research instruments (Boix, Stokes, \& Gerring, 2009; Pearson, Albon, \& Hubball, 2015). Although the research provided the results for a case study, the analysis of a single institution cannot be generalized to fit different cases (Ellram, 1996). However, the research framework and study design were selected to gain insights into how the learners of a particular institution improved their language profile and what their perspectives were on using pair taping in the classroom (Samaranayake, 2016), so that a future study will be able to validate the results and implications of the study.

\subsection{Participants}

The participants in the research were 50 first-year learners at a university in Tokyo. They were selected because their English learning experience before entering the institution was similar to the average proficiency level of Japanese tertiary-level English learners, that is, their English proficiency level was lower-intermediate, they had had very few opportunities to speak English outside the classroom, and no learners had experienced living abroad. The learners received two English classes with 1.5 hours of lessons every week. The purpose of the English classes was to develop their oral and listening communication skills in English. The learners were given instructions regarding the procedures of pair taping, including how to record their conversations using a voice memo application on a mobile phone and how to analyze their spoken discourse using an online lexical analysis tool, VocabProfile (Cobb, 2002). 


\subsection{Instruments}

In order to record the learners' conversation, the voice memo application on a mobile phone was used because of its usability and mobility. Although all learners possessed their own mobile phone, several recording devices were prepared in case a mobile phone needed a battery charge. VocabProfile was adopted to measure the level of vocabulary the learners spoke. This is an online program that sorts the vocabulary of spoken data into four categories: the 1,000 most frequent words (referred to as "K1"), the next 1,000 most frequent words (K2), the 570 most frequently used academic words (AW) (as proposed by Coxhead (1998)), and others words (OFF). VocabProfile also provides the lexical density (LD), which indicates the ratio of content words used (e.g., nouns, verbs, adjectives, and adverbs) to function words (e.g., articles and prepositions). VocabProfile was chosen because it is easy to use for EFL learners. Although the instructions were provided in English, most procedures were simple and straightforward. The computer automatically categorized the transcription of spoken data into four categories by frequency. In this way, learners can visualize their progress, the number of the words they spoke and the level of the vocabulary they used.

At the end of the fifteenth lesson, the researcher administered an open-ended questionnaire with four questions adapted from Schneider (2001): 1) Do you think you have gained fluency through pair taping? 2) Do you think your lexical profile has improved? 3) What do you think you should do to improve your speaking fluency? and 4) What do you think you should do to improve your vocabulary proficiency? The first and second questions had the following scored responses: (5) Yes, very much, (4) Yes, pretty much, (3) Yes and no, (2) No, not very much, (1) No, not at all.

\subsection{Treatment}

Before coming to the class, the learners were required to read a textbook that targeted the development of speaking ability and to prepare their answers and ideas for each unit's conversation exercises. Some of the example questions were, "What do you like the best about your school/faculty?" and, "Where would you like to visit if you were offered a free trip to abroad this summer?" At the beginning of each class, the researcher gave the name list of pairs to inform learners of who their partners would be and where to sit. The seating order was developed so that each learner had approximately five to seven different partners in one class.

All learners had mobile phones with a recording function and a voice memo application, with which the whole conversations were recorded and utilized for transcription after the conversation phase. At the beginning of each class, the researcher made sure that all learners had their first partner and their mobile phones ready for recording. The learners were then asked to stand up and prepare for the recording. When the researcher said, "Please start," the learners started recording and holding a conversation. Each pair spoke for three minutes about the textbook questions, icebreaking topics (e.g., questions about what they did during the weekend), and ending topics (e.g., expressing gratitude for the conversation and farewells). After three minutes, each pair finished their recording and were asked to move to the next pair's seat.

This procedure was repeated five to seven times a class. After all pair taping, the learners moved to a computer room to transcribe their conversations in a Microsoft Word file. Once the conversations were transcribed, they were pasted into VocabProfile and submitted for analysis. The typical procedures of pair taping are provided in Table 1.

\subsection{Data analysis}

Regarding the numerical data obtained from the vocabulary profile analysis using VocabProfile, a paired-samples t-test was conducted to compare the lexical profiles (total words, K1, K2, AW, OFF, and LD) of the first and final classes' pair taping. As for the open-ended questionnaire, the researcher read the responses, calculated the scores of the first and second questions and analyzed the content of the written responses, adopting qualitative research procedures (Strauss \& Corbin, 1990; Atmowardoyo, 2018). The data were analyzed 
Ichiyama, Y.

and checked thematically by another academic researcher to ensure reliability.

\section{Table 1}

Procedures of Pair Taping

\begin{tabular}{ll}
\hline \multicolumn{1}{c}{ Phase } & \multicolumn{1}{c}{ Procedures } \\
\hline Before class & Read textbook conversation questions and prepare answers \\
In class & Go to $1^{\text {st }}$ partner's seat with a mobile phone \\
& Start conversation with $1^{\text {st }}$ partner and recording \\
& Finish conversation with $1^{\text {st }}$ partner and recording \\
& Move to $2^{\text {nd }}$ partner's seat \\
& Start conversation with $2^{\text {nd }}$ partner and recording \\
& Finish conversation with $2^{\text {nd }}$ partner and recording \\
& Move to $3^{\text {rd }}$ partner's seat \\
& Start conversation with $3^{\text {rd }}$ partner and recording \\
& Finish conversation with $3^{\text {rd }}$ partner and recording \\
& $\ldots$ \\
& Move to a final partner's seat \\
& Start conversation with final partner and recording \\
& Finish conversation with final partner and recording \\
Go to the computer room \\
After class & Play the recorded conversation and transcribe it in a Word file \\
& Open VocabProfile, paste the transcription, and proceed to analysis \\
& Submit the analysis results and recorded file to the researcher \\
\hline
\end{tabular}

\section{Results and Discussion}

The table 2 shows the basic statistics of the first and the last pair taping's lexical profile. While there was a significant difference between the total amount of words they spoke in first and final pair taping $($ mean $(M)=80$, standard deviation $(\mathrm{SD})=33$ and $\mathrm{M}=99, \mathrm{SD}=24$, respectively; $t(49)=-3.98 ; p=.0001)$, there were no significant differences between the first and the final pair taping regarding $\mathrm{K} 1(\mathrm{M}=66, \mathrm{SD}=5$ and $\mathrm{M}=81, \mathrm{SD}$ $=5$, respectively; $t(49)=0.5, p=.7), \mathrm{K} 2(\mathrm{M}=5, \mathrm{SD}=2$, and $\mathrm{M}=6, \mathrm{SD}=3$, respectively; $t(49)=0.41 ; p=.66)$, $\mathrm{AW}(\mathrm{M}=1, \mathrm{SD}=1$, and $\mathrm{M}=1, \mathrm{SD}=1$, respectively; $t(49)=-1.66 ; p=.05), \mathrm{OFF}(\mathrm{M}=8, \mathrm{SD}=1$, and $\mathrm{M}=11$, $\mathrm{SD}=4$, respectively; $t(49)=-1.03 ; p=.15)$, and $\mathrm{LD}(\mathrm{M}=40, \mathrm{SD}=4$, and $\mathrm{M}=50, \mathrm{SD}=5$, respectively; $t(49)=$ $1.06 ; p=.8)$. The fact that there were no significant differences between the first and the last pair taping indicates the need to increase more pre-task input, especially that of variety in expression. Moreover, some of the topics, such as summer plans, were inappropriate because the activity took place after the summer vacation. As Derakhashan, Khalili, and Beheshti (2016) point out a careful selection of materials and topics is needed for the successful implementation of oral communication activities.

Table 2

Average and SD Values of Lexical Profiles

\begin{tabular}{lcccc}
\hline & \multicolumn{2}{c}{ First pair taping } & \multicolumn{2}{c}{ Last pair taping } \\
& Average & $S D$ & Average & $S D$ \\
\hline Total words & 80 & 33 & 99 & 24 \\
K1 & 66 & 5 & 81 & 5 \\
K2 & 5 & 2 & 6 & 3 \\
AW & 1 & 1 & 1 & 1 \\
OFF & 8 & 1 & 11 & 4 \\
LD & 40 & 4 & 50 & 5 \\
\hline
\end{tabular}

The results of learners' responses to questions 1 and 2 regarding pair taping are listed in Table 3 . The majority of learners responded positively to question 1, which asked about their progress in speaking fluency. The result is consistent with the preceding results of the statistical analysis regarding the total words spoken in first and last pair taping. In the final pair taping, many commented that they could speak more fluently than in 
Using vocabulary profile for pair taping to improve speaking practices at a class for EFL

the first pair taping. The fact that many learners felt progress in their fluency is shown in their comments. Many reported that they became relaxed and used to speaking with their partners after several pair tapings and actually started to enjoy the process. The results appear to indicate that the introduction of pair taping to EFL classrooms with low proficiency is beneficial for increasing motivation to speak freely in English.

Table 3

Learners' Responses Regarding Pair Taping

\begin{tabular}{cccccc}
\hline & (5) Yes, very much & (4) Yes, pretty much & (3) Yes and no & (2) No, not very much & (1) No, not at all \\
\hline Q 1 & $37(74 \%)$ & $7(14 \%)$ & $4(8 \%)$ & $1(2 \%)$ & $1(2 \%)$ \\
Q 2 & $7(14 \%)$ & $6(12 \%)$ & $22(44 \%)$ & $11(22 \%)$ & $4(8 \%)$ \\
\hline
\end{tabular}

In the case of question 2 on learners' views of lexical profile progress, nearly half of the learners responded that they were not sure of their progress, and only a fourth of learners replied positively to the question. These responses are consistent with the results of the comparison of the lexical profiles, which did not show significant differences between the first and last pair tapings. These results can be attributed to the use of communication strategies, such as simplification or avoidance, where learners use easy terms because they could not come up with appropriate terms and did not want to stop the flow of conversation (Cohen \& Olshtain, 1993). These results suggest a need to provide a list of various expressions and phrases to increase variation in the learners' lexical profiles.

In regard to question 3, which asked about learning strategies for improving fluency, many learners claimed that they needed exposure to more practice in speaking English, as well as intensive study in the classroom. Some commented that they needed to speak to native English-language speakers outside the classroom. The results appear to indicate a need to increase not only the amount of pair taping activity inside the classroom but also to provide opportunities to engage in pair taping outside the classroom. In fact, many of the pair taping studies took place outside classrooms and were reported to be very successful (Kluge \& Taylor, 1998, 2000; Schneider, 2001).

For question 4 regarding learning strategies for developing lexical profiles, many learners commented that they needed to learn more essential vocabulary for daily conversation. Some commented that they regret being silent during the pair taping. Among such learners, some reflected more deeply and mentioned that preparing for the pair taping using a written form was not sufficient and that practice speaking repeatedly before the pair taping was important. The results are consistent with previous research where many EFL learners considered oral and written repetition of new words as the most effective strategies for gaining lexical proficiency (Lawson \& Hogben, 1996). The results appear to indicate a need to develop pre-pair-taping activities. Learners were only required to prepare for the exercise on a sheet of paper, but in the future, oral rehearsal might be one of the options to prepare for the pair taping.

Having conducted the study, the researcher found that the implementation of pair taping and lexical profile analysis by learners may enhance learners' oral communication skills and their motivation to speak in the EFL classroom. Learners can be exposed to practice their oral communication skills with various people who possess differing proficiency, values, and knowledge. Some learners struggled in responding to the most frequently used ending remarks such as "I enjoyed talking with you" because she had never experienced such an exchange apart from "bye" or "see you." Repeated practice with many partners enables the learners to acquire basic communication skills to maintain their conversation, especially when they face a communication deficit caused by language problems. Moreover, by reflecting on their conversations through the lexical analysis of their spoken interaction encourages the learners to use a variety of expressions.

Teachers in EFL contexts may also benefit from implementing pair taping and lexical profile analysis to acknowledge what is needed for the learners to acquire because the measurement of leaners' vocabulary profile is provided every lesson. The reading of the learners' transcription provides for rich data for analysis with 
regards to each learner's knowledge of vocabulary, expression, and communication strategies. Moreover, the pair-taping activities enable the teachers to actually observe learners' speaking practices and therefore provide needed assistance and advice on time.

\section{Conclusion}

Although the development of speaking fluency in English is one of the most frequently addressed themes in teaching EFL, it is also one of the most challenging problems for educationalists and researchers in the field of EFL (Zhang 2009; Gudu, 2015; Albino, 2017; Samaranayake, 2016). This study highlights the need to provide not only the pair taping activities but also opportunities to practice for the pair-taping to acquire lexical fluency in their spoken discourse.

The study has several limitations, especially the small sample size and relatively short period of time used for exposing the learners to pair taping. Moreover, there is a need for more sophisticated pre-pair taping activities so that the learners could be provided with a variety of ways to express their opinions and ideas. In the future studies, there is a need to explore whether learners with different proficiency levels such as advanced-level learners exhibit similar results regarding lexical profile and motivation.

Acknowledgements: This work was supported by JSPS KAKENHI Grant-in-Aid for Scientific Research (C), No. 18K00887.

\section{References}

Abduh, A., \& Rosmaladewi, R. (2017). Taking the Lextutor on-line tool to examine students' vocabulary level in business English students. World Transactions on Engineering and Technology Education, 15(3), 283-286.

Albino, G. (2017). Improving speaking fluency in a task-based language teaching approach: The case of EFL learners at PUNIV-Cazenga. SAGE Open, 7(2). https://doi.org/10.1177/2158244017691077

Angga, A. M. (2013). The use of pair taping to teach speaking of recount text to the Eighth grade students. RETAIN, 1(3), 1-10.

Atmowardoyo, H. (2018). Research methods in TEFL studies: Descriptive research, case study, error analysis, and R\&D. Journal of Language Teaching and Research, 9(1), 197-204.

https://doi.org/10.17507/jltr.0901.25

Boix, C., Stokes, S., \& Gerring, J. (2009). The case study: What it is and what it does. In R. E. Goodin (Ed.), Oxford handbook of comparative politics. Oxford University Press. https://doi.org/10.1093/oxfordhb/9780199566020.003.0004

Brown, H. D. (2001). Teaching by principles: An interactive approach to language pedagogy (2nd ed.). New York: Pearson Education.

Burns, A., \& Hill, D. (2013). Teaching speaking in a second language. In B. Tomlinson (Ed.), Applied linguistics and materials development (pp. 231-248). New York, NY: Bloomsbury Academic. https://doi.org/10.5040/9781472541567.ch-015

Cobb, T. (2002). Web VocabProfile. Retrieved from https://www.lextutor.ca/

Cohen, A. D., \& Olshtain, E. (1993). The production of speech acts by EFL learners. TESOL Quarterly, 27(1), 33-56. https://doi.org/10.2307/3586950

Coxhead, A. (1998). An academic word list (Vol. 18). School of Linguistics and Applied Language Studies.

Daller, M. H., \& Xue, H. (2009). Vocabulary knowledge and academic success: A study of Chinese students in UK higher education. In Vocabulary studies in first and second language acquisition (pp. 179-193). London: Palgrave Macmillan. https://doi.org/10.1057/9780230242258_11

Derakhshan, A., Khalili, A. N., \& Beheshti, F. (2016). Developing EFL learner's speaking ability, accuracy and fluency. English Language and Literature Studies, 6(2), 177-186. https://doi.org/10.5539/ells.v6n2p177 
Using vocabulary profile for pair taping to improve speaking practices at a class for EFL

Ellram, L. M. (1996). The use of the case study method in logistics research. Journal of Business Logistics, 17(2), 93-138.

Engber, C. A. (1995). The relationship of lexical proficiency to the quality of ESL compositions. Journal of Second Language Writing, 4(2), 139-155. https://doi.org/10.1016/1060-3743(95)90004-7

Gould, T. (2009). Assessing lexical production in NNS-NNS casual conversations: A mini-corpus approach. Sophia Junior College Faculty Journal, 29, 25-45.

Gudu, B. O. (2015). Teaching speaking skills in English language using classroom activities in secondary school level in Eldoret Municipality, Kenya. Journal of Education and Practice, 6(35), 55-63.

Herlina, H., \& Holandiyah, M. (2015). Teaching speaking skill by using guided conversation technique through pair taping to the seventh grade learners of SMP PTI Palembang. Edukasi: Jurnal Pendidikan dan Pengajaran, 2(2), 107-120.

Humphries, S. C., Burns, A., \& Tanaka, T. (2015). "My head became blank and I couldn't speak": Classroom factors that influence English speaking. The Asian Journal of Applied Linguistics, 2(3), 164-175.

Iwashita, N. (2005). An investigation of lexical profiles in performance on EAP speaking tasks. Spaan fellow working papers in second or foreign language assessment Vol. 3 2005, 1001, 101. Retrieved from https://michiganassessment.org/wp-content/uploads/2014/12/Spaan_V7_FULL.pdf

Jin, T., Guo, K., Mak, B., \& Wu, Q. (2017). Lexical profiles of reading texts in high-stakes tests: Where are the benchmarks? International Journal of Computer-Assisted Language Learning and Teaching (IJCALLT), 7(1), 34-49. https://doi.org/10.4018/ijcallt.2017010103

Kim, Y. M. (2010). Spoken corpora of EFL learners: Collocations, vocabulary use, and their oral proficiency levels. Multimedia Assisted Language Learning, 13(1), 9-28.

Kimura, Y., Nakata, Y., Ikeno, O., Naganuma, N., \& Andrews, S. (2017). Developing classroom language assessment benchmarks for Japanese teachers of English as a foreign language. Language Testing in Asia, 7(1), 3. https://doi.org/10.1186/s40468-017-0035-2

King, J. (2012). Silence in the second language classrooms of Japanese universities. Applied Linguistics, 34(3), 325-343. https://doi.org/10.1093/applin/ams043

Kluge, D. E., \& Taylor, M. A. (2000). Boosting speaking fluency through partner taping. The Internet TESL Journal, 6(2). Retrieved from http://iteslj.org/Techniques/Kluge-PartnerTaping

Kluge, D., \& Taylor, M. A. (1999). Outside taping for fluency: A practical system. JALT98: Proceedings, 27-32. https://doi.org/10.12968/prps.1999.1.18.41115

Kubo, M. (2007). Examining self-confidence variables: An action research inquiry into pair taping (PT) efficacy. Accents Asia, 1(3), 42-62.

Kubo, M. (2009). Extensive pair taping for college students in Japan: Action research in confidence and fluency building. Accents Asia, 3(1), 36-68.

Kubo, M. F. (2013). Pair taping turns twenty: A new look at an old method. The Quarterly Journal of Rissho Economics Society, 63(1), 131-146.

Laufer, B., \& Nation, P. (1995). Vocabulary size and use: Lexical richness in L2 written production. Applied Linguistics, 16(3), 307-322. https://doi.org/10.1093/applin/16.3.307

Lawson, M. J., \& Hogben, D. (1996). The vocabulary-learning strategies of foreign-language students. Language Learning, 46(1), 101-135. https://doi.org/10.1111/j.1467-1770.1996.tb00642.x

Lobin, H., \& Rösler, D. (2012). Tutoring systems and Computer-Assisted Language Learning (CALL). In A. Mehler, \& L. Romary (Eds.), Handbook of technical communication (pp.571-589). Berlin, Germany: Mouton de Gruyter. https://doi.org/10.1515/9783110224948.571

$\mathrm{Lu}, \mathrm{X}$. (2012). The relationship of lexical richness to the quality of ESL learners' oral narratives. The Modern Language Journal, 96(2), 190-208. https://doi.org/10.1111/j.1540-4781.2011.01232.x

Ministry of Education, Culture, Sports, Science, and Technology. (2003). Regarding the establishment of an action plan to cultivate "Japanese with English abilities. Retrieved from http://www.mext.go.jp/enfflish/topics/03072801.htm

Nakatani, Y. (2006). Developing an oral communication strategy inventory. The modern language journal, 90(2), 151-168. https://doi.org/10.1111/j.1540-4781.2006.00390.x 
Ichiyama, Y.

Nunan, D. (1999). Second language teaching \& learning. Florence, KY: Heinle \& Heinle Publishers.

Ohata, K. (2005). Potential sources of anxiety for Japanese learners of English: Preliminary case interviews with five Japanese college students in the US. TESL-EJ, 9(3), n3.

Pearson, M. L., Albon, S. P., \& Hubball, H. (2015). Case study methodology: Flexibility, rigour, and ethical considerations for the scholarship of teaching and learning. Canadian Journal for the Scholarship of Teaching and Learning, 6(3), 12. https://doi.org/10.5206/cjsotl-rcacea.2015.3.12

Raba, A. A. A. (2017). The influence of think-pair-share (TPS) on improving students' oral communication skills in EFL classrooms. Creative Education, 8(1), 12. https://doi.org/10.4236/ce.2017.81002

Samaranayake, S. W. (2016). Oral competency of ESL/EFL learners in Sri Lankan rural school context. SAGE Open, 6(2). https://doi.org/10.1177/2158244016654202

Sato, M., \& Lyster, R. (2012). Peer interaction and corrective feedback for accuracy and fluency development: Monitoring, practice, and proceduralization. Studies in Second Language Acquisition, 34(4), 591-626. https://doi.org/10.1017/s0272263112000356

Schneider, P. (1993). Developing fluency with pair taping. JALT Journal, 15(1), 55-62.

Schneider, P. H. (1997). Using pair taping. The Internet TESL Journal, 3(2).

Schneider, P. H. (2001). Pair taping: Increasing motivation and achievement with a fluency practice. TESL-EJ, 5(2), 1-32.

Setiyorini, Y. A. (2013). Improving the learner's speaking practices at the eleventh grade learners of Sma N 1 Gombong through pair-taping in the academic year of 2012/2013 (Unpublished doctoral thesis). Yogyakarta State University, Indonesia.

Stock, A. G. (2010). The impact of the Ontario secondary school literacy test on L2 students (Doctoral dissertation). Carleton University, Canada.

Strauss, A., \& J. Corbin. (1990). Basics of qualitative research: Procedures and techniques of grounded theory. New York: Sage Publication.

Syamdianita, S., Ismail, N., \& Nur, D. R. (2018). Pair taping for undergraduate EFL learners' speaking fluency and self-confidence. Script Journal: Journal of Linguistic and English Teaching, 3(2), 163-174. https://doi.org/10.24903/sj.v3i2.203

Yanagi, M., \& Baker, A. A. (2016). Challenges experienced by Japanese learners with oral communication skills in Australian universities. TESOL Journal, 7(3), 621-644. https://doi.org/10.1002/tesj.229

Zhang, S. (2009). The role of input, interaction and output in the development of oral fluency. English Language Teaching, 2(4), 91-100. https://doi.org/10.5539/elt.v2n4p91 